\title{
JENNY LAKE LODGE AND CABINS, DETERMINATION OF ELIGIBILITY FOR THE NATIONAL REGISTER OF Historic Places
}

\author{
MARY M. HUMSTONE $\uparrow$ HILERY WALKER $\uparrow$ HELIS SIKK \\ UNIVERSITY OF WYOMING $\uparrow$ LARAMIE
}

\begin{abstract}
During summer 2009, the University of Wyoming American Studies Program conducted an intensive historic building and landscape survey of the Jenny Lake Lodge in Grand Teton National Park (Figure 1). The oldest of Grand Teton Lodge Company's visitor accommodations, Jenny Lake Lodge has a long and varied history that spans the period from early $20^{\text {th }}$ century dude ranching to contemporary automobile tourism, and that is closely entwined with the history of Grand Teton National Park itself.
\end{abstract}

Research scientist Mary Humstone, working with graduate assistants Hilery Walker and Helis Sikk, researched and documented the Jenny Lake Lodge property and compiled the results into a "Wyoming Cultural Properties Form" which was submitted to the National Park Service in January, 2010. Each building was carefully examined to determine approximate date and type of construction, and identify additions and other alterations. A typology of $\log$ cabins was developed to facilitate understanding of the different cabin types on the property, and when they were built. The landscape of the 17-acre property was also documented and analyzed for historic significance. Photographs were taken of all buildings and major landscape features. Primary materials such as blueprints and historic photographs were consulted to confirm dates of buildings and additions. Additional archival research and oral interviews were conducted to document the history of the property and evaluate whether it retains enough significance to warrant listing on the National Register of Historic Places.

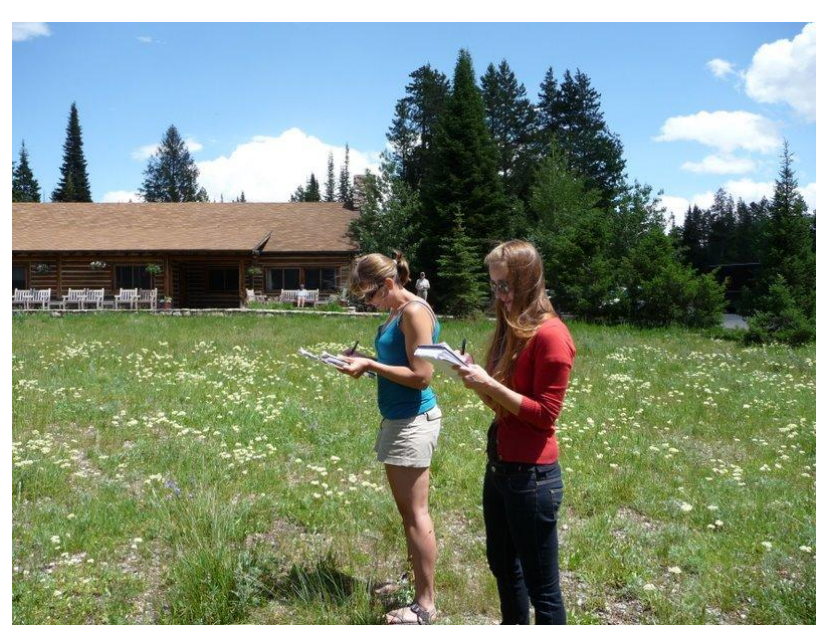

Figure 1. Hilery Walker (1) and Helis Sikk record the architectural features of the main lodge at Jenny Lake Lodge (Mary Humstone, 2009)

\section{Cultural Significance of Jenny Lake Lodge}

Jenny Lake Lodge is significant as one of the longest operating tourist establishments in Grand Teton National Park. Founded in 1922 as the Danny Ranch, the property has provided Park visitors with lodging, food and outdoor activities almost continuously for 87 years. Jenny Lake Lodge embodies a social history that places it squarely between a traditional dude ranch and a guest lodge or hotel. While guests can drop in and spend just one night at the lodge, much more common are guests who return year after year, for stays of one week or more, in the tradition of dude ranches. 
Jenny Lake Lodge occupies a special niche in the tourism culture of Grand Teton National Park. It is the smallest and most expensive of the three lodging facilities operated by the Grand Teton Lodge Company. It has a very personal, intimate feel as opposed to the much larger Jackson Lake Lodge, yet it is by no means deluxe. Cabins are small by today's standards and simply furnished. The lodge is cozy and comfortable but not luxurious. The restaurant is known for fine dining. Much like a guest ranch, breakfast and dinner are included in the price of the room, as are horseback riding and the use of a bicycle.

Jenny Lake Lodge has outlasted other historic dude ranches in the Park, such as the White Grass Ranch and the Bar BC, and has operated longer than the other lodges, such as Jackson Lake Lodge, Colter Bay Cabins and Signal Mountain Lodge. The property represents a long history of tourism in the area, and reflects the changes in the tourism industry over the past $80+$ years. Jenny Lake Lodge also represents the history of Grand Teton National Park, since it was one of the properties purchased by J.D. Rockefeller's Snake River Land Company for inclusion in the Park, and has been at the center of many debates over what visitor amenities the Park should offer.

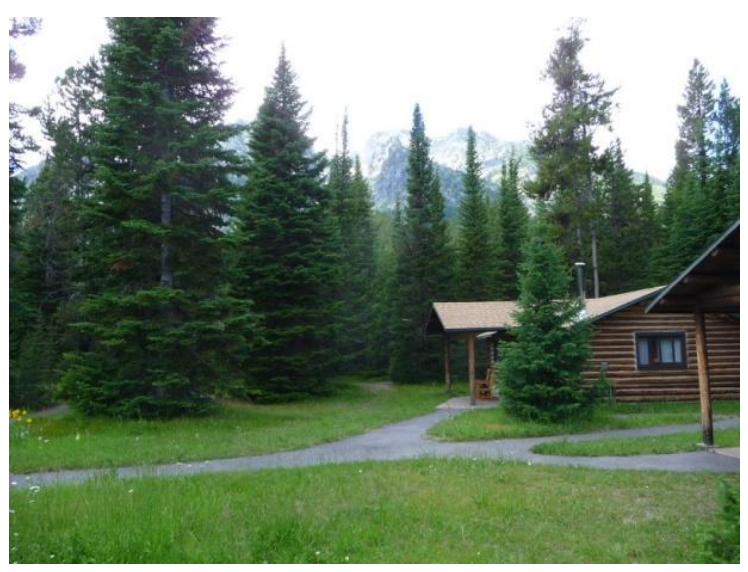

Figure 2. Cabins and landscaping, with Tetons in background (Mary Humstone, 2009).

In addition to its historical significance, Jenny Lake Lodge is significant as a cultural landscape embodying concepts of Western-style hospitality, including rustic cabins and a comfortable lodge and dining room, set in a natural landscape with a magnificent view (Figure 2). The lodge itself has been changed many times in its 87-year history, yet still retains the oiled log walls and rustic atmosphere of the original (Figure 3). Forty-one of the 47 buildings on the property date from the period of significance (1922-1957), and all represent the same tradition of $\log$ construction with rectangular floor plans, low- to medium-pitched purlin roofs, open porches and simple interiors with exposed log walls. Newer guest cabins were built to mimic the old, resulting in a collection of buildings that are similar and yet not identical.

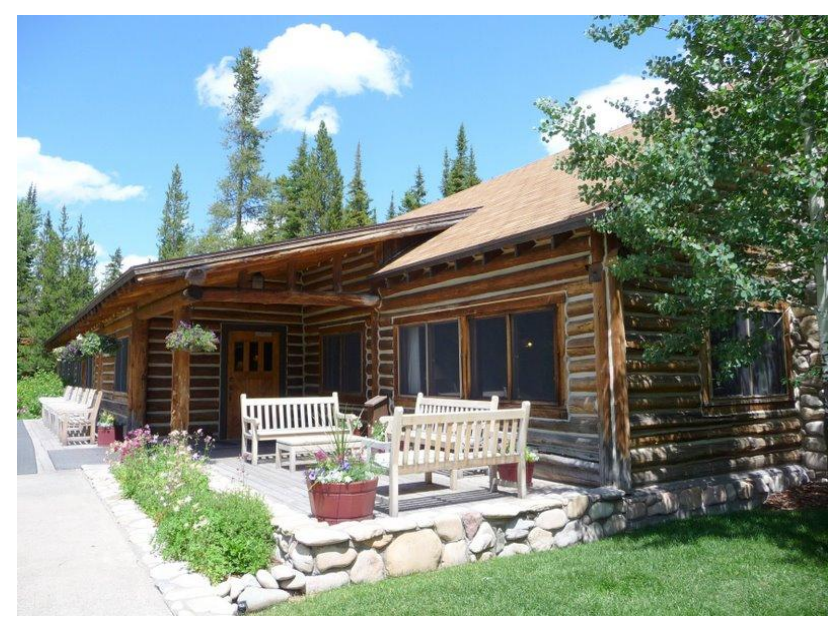

Figure 3. Main lodge at Jenny Lake Lodge (Mary Humstone, 2009)

\section{History of Jenny Lake Lodge}

For more than 10,000 years, people have been visiting Jenny Lake, beginning with Native Americans who traveled to the area during the summer months for hunting and fishing. In the midto-late 1800 s, trappers in search of beaver pelts began exploring the mountains and valleys, bestowing upon the jagged peaks the name "Les Trois Tetons." The first documented visit to Jenny Lake occurred in 1872, when mountain man and trapper "Beaver Dick" Leigh and his family accompanied Dr. Ferdinand Hayden, Thomas Moran and other members of the Hayden Expedition to the area. It is for Leigh's Shoshone wife, Jenny Leigh, that the lake was named.

Because of its remote and inaccessible location, the northwest corner of Wyoming was slow to develop, and it was not until the mid 1880s that homesteaders began to settle in Jackson Hole. Homesteaders favored the flat grazing lands over rugged mountainous terrain, and thus the lands around Jenny Lake were even slower to develop than areas to the south and east. When the Jenny Lake area was first surveyed in 1902, only one cabin was identified (Toogood 1974). 
Although the land around Jenny Lake was not favorable for raising cattle or farming, its scenic value was well recognized, and with the growth of tourism in Jackson Hole in the early $20^{\text {th }}$ century, the Jenny Lake area began to develop. The forested land around the lake, which was included in the Teton Forest Reserve established in 1897, was managed by the U.S. Forest Service for both commercial and recreational values, resulting in leasing of land for tourist concessions as well as lumbering, mining and irrigation.

\section{Danny Ranch}

The property now known as Jenny Lake Lodge was homesteaded in 1922 by a cowboy, guide and outfitter named Tony Grace. Grace had worked as a cowboy at the Bar BC Ranch, established in 1912 by Struthers Burt and Horace Carncross. The success of the Bar BC inspired several of its former employees (and guests) to open their own dude ranches in the 1920s. With the financial backing of New Jersey silk manufacturer Albert Bruton Strange, whom Grace befriended while working at the Teton Lodge and Bar BC dude ranches, Grace filed on a 160-acre homestead just east of Jenny Lake with the intention of establishing his own dude ranch. He dubbed his new property the "Danny Ranch" in honor of Albert Strange's daughter, "Danny," of whom Grace was reputedly quite fond. Grace proved up on his land and received a patent under the Homestead Act on January 17, 1928.

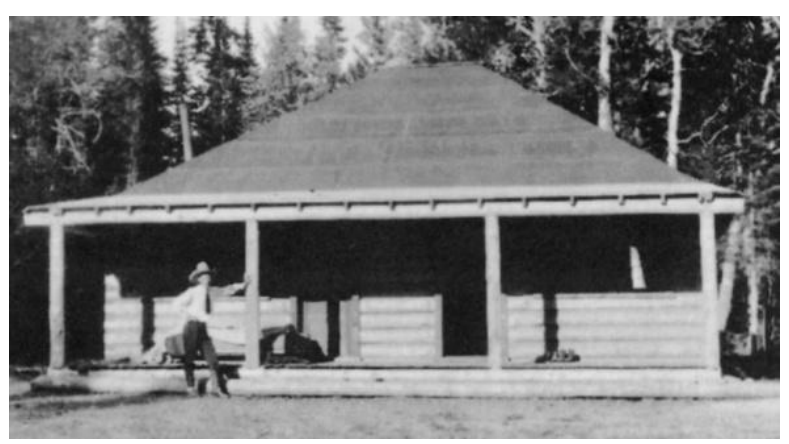

Figure 4. Original Main Lodge, c. 1928 - now the dining room (McKinney).

In developing his dude ranch, Tony Grace followed a well-established local tradition. The use of the Homestead Act for land speculation and commercial development was common in the Jackson Hole area. "[Homesteaders] capitalized on the unspoiled scenic beauty of the region and its abundant wildlife to create dude ranches, residences, vacation homes, hunting lodges or tourist courts."
(Caywood and Hubber 1997). The JY Ranch, the White Grass Ranch, the Trail Ranch and the Bar BC were all originally filed as homesteads. Also common was the practice of a wealthy investor (often from the East) going into the dude ranching business in partnership with a local wrangler (Caywood and Hubber 1997).

Although Tony Grace established his ranch in the middle of the "golden decade of dude ranching," his operation was slightly different from the traditional dude ranches, which ran cattle and gave guests an opportunity to participate in the daily chores of cattle ranching. The Danny Ranch was closer to a "guest ranch," where guests stayed in rustic but comfortable accommodations and enjoyed activities such as fishing, hiking, and recreational horseback rides to scenic places.

Initially the Danny Ranch consisted of a 30'-by-30' three-room lodge, a barn, an icehouse and two cabins (Mary McKinney 1997). Using local materials like lodgepole pine and stone, Grace constructed the buildings in the local vernacular tradition. Round logs were peeled and fashioned together using the traditional saddle notching that was common to the area. Roofs were constructed of a $\log$ ridgepole and purlins and topped with board planking. One of Grace's original guest cabins still exists in close to original form. The eave-front, gable-roofed cabin has a center log partition, indicating its separation into two rooms.

The original three-room lodge was unusual because of its square shape and pyramidal hipped roof, a building form rare in the Rocky Mountain West (Figure 4). This building still exists, although after many renovations and additions, only its exterior walls remain and those are encased in later additions. Its original ceiling finished in lodgepole saplings remained intact until a major renovation in 1986.

According to Grand Teton Lodge Company historian Mary McKinney, during the Danny Ranch's first five years of operation, the number of visitors increased from 23 in 1923 to 54 in 1928. The oneman guest ranch operation catered to elite Easterners searching for a "frontier experience." The Strange family and their friends were regular visitors at the ranch, as was prolific silent film actor and director Tom Moore. Like many dude ranch operators, Tony Grace made several wintertime visits to the Strange family and other East Coast contacts to recruit new guests. 
In 1928, after receiving the patent to his land, Grace made some improvements to the property, adding a large stone fireplace to the north end of the main lodge, building a small gabled log addition off the south end and constructing two more guest cabins. The 1928 cabins are one room each, with low-pitched gable roofs and entrances in the gable ends (Figure 5).

While Tony Grace was establishing and running his dude ranch, other developments were occurring around him that would eventually force him to sell his land. Led by Yellowstone National Park Superintendent Horace Albright, a movement to protect the Jackson Hole valley from development was gaining momentum. In 1926, Albright persuaded John D. Rockefeller, Jr. to take a drive from Yellowstone Park to Jackson Hole. Horace Albright, often called the "Father of the National Park System," had already proclaimed in 1915 that "this glorious valley must be preserved for and against future generations." (Huyler 2000). Rockefeller's interests in conservation were ignited by this visit. "Rockefeller and his wife were profoundly impressed by the Leigh-String-Jenny Lake region, but were appalled by the encroaching commercialism. A rather tawdry dancehall seemed inappropriate, 'unsightly structures' marred the road and telephone wires bisected the Teton view." (Righter 1982).

In 1927, Rockefeller founded the Snake River Land Company, which began buying up properties in Jackson Hole with the ultimate goal of donating them to the National Park Service. Two years later, Congress created Grand Teton National Park, which encompassed the former Forest Reserve land directly west of Danny Ranch. While this action removed some land from development, it also created a need for infrastructure to serve the tourists who were drawn to the Park. The Grand Teton Transportation Company and Grand Teton Lodge Company were formed to "provide lodging and transportation for tourists in cooperation with the Yellowstone and Grand Teton National Parks." Together with the National Park Service, the Grand Teton Lodge Company relocated buildings from the properties bought by the Snake River Land Company to "designated tourism locations in within the park." (Grand Teton Lodge Company files, Grand Teton National Park Historian's Office, Moose WY).

Jenny Lake was a natural choice for a tourism destination. A road, campground and boat concession had already been developed at the south end of the lake under a Forest Service lease. In 1930, the former Lee Mangus cabin was moved from
Cottonwood Creek to the south end of Jenny Lake to serve as a museum, ranger station, and staff residence, and Jenny Lake became the hub of activities in the Park: "mountain climbers, campers, boating enthusiasts, hikers all began their park visit from this point." (Toogood 1974).

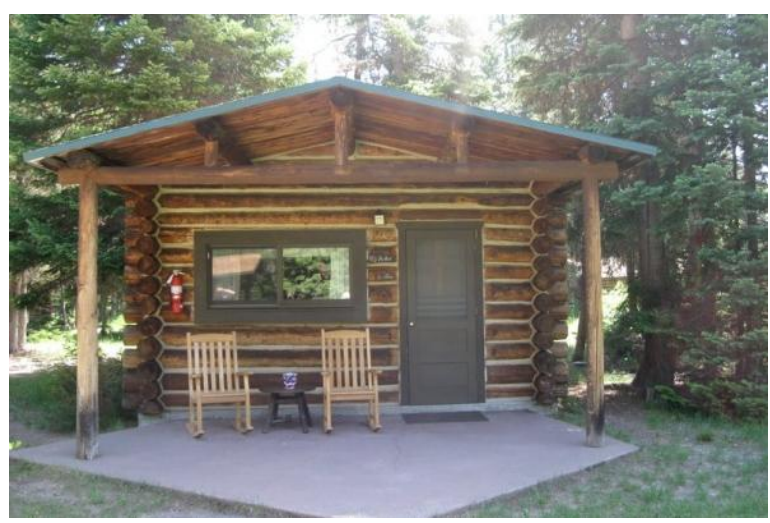

Figure 5. Fireweed, built by Tony Grace in 1928 (Hilery Walker, 2009)

The Danny Ranch's isolated, "getaway" feel was diminished by these developments and by the increased tourist traffic generated by improvements made to the Teton Park Road, which was realigned and paved in the late 1920s. Because of its prime location at Jenny Lake, Tony Grace's Danny Ranch was a natural target of the Snake River Land Company, and Grace came under pressure to sell. In 1930, "feeling hemmed in by the new park" and pressured by the Snake River Land Company, Grace sold his ranch to the company for $\$ 24,000$. Although the terms of the sale allowed Grace to continue running the ranch until June 1, 1932, in the fall of 1931 he packed all of his possessions onto his horses and drove them through Yellowstone Park to new land he had purchased in Montana.

\section{Jenny Lake Ranch}

From 1932 to 1936, the Danny Ranch was closed to the public while the Park Service and the Snake River Land Company debated what to do with the ranch buildings. The Park Service wanted to restore the area to its natural condition, while the concessionaire continued to stress the need for visitor accommodations within or adjacent to the Park. A Park Service memo of the time described the Danny Ranch in disparaging terms, noting that it was "only a site with an old lodge that was just a shell and small cabins that were only shacks"(McKinney 1997).

This debate was resolved in 1937 when the Park Service finally allowed the Snake River Land Company to lease the Danny Ranch to the Grand 
Teton Lodge Company (GTLC). The Danny Ranch was renamed Jenny Lake Ranch, and the GTLC constructed several more guest cabins, four of which exist today. These cabins matched the existing cabins in form, materials and workmanship. Two of the 1937 cabins are gable-front single cabins (Figure 6) while the other two are larger cabins with eave-front gable roofs similar to Grace's original cabins. The new cabins were plumbed and equipped with private baths, and hot and cold running water was added to the existing cabins. At this time, a dining room and kitchen were added to the south end of the main lodge, replacing Grace's 1928 addition.

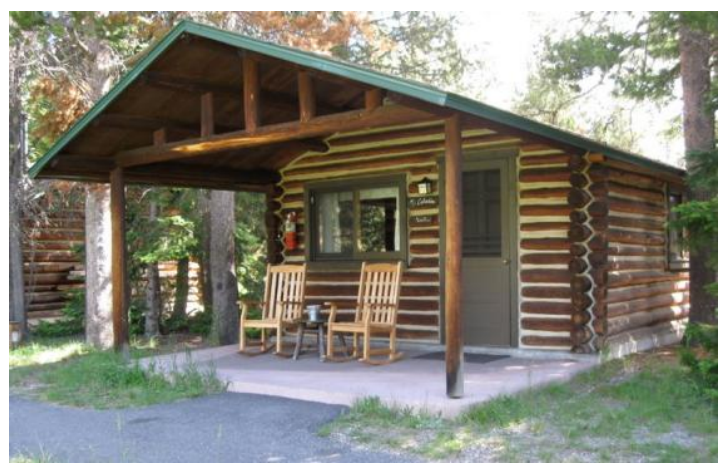

Figure 6. Columbine, a gable-front single cabin built by the Grand Teton Lodge Company in 1937 (Hilery Walker 2009)

The addition of new cabins brought the guest capacity up to 65, and Jenny Lake Ranch enjoyed several prosperous years. However, when the United States entered World War II, Jenny Lake Ranch and other Jackson Hole visitor facilities were closed down because "gas rationing greatly curtailed travel for the American public.” (McKinney 1997).

Meanwhile, administrative changes were taking place that affected the ownership of the Jenny Lake Lodge property. On March 15, 1943, at the urging of John D. Rockefeller, President Roosevelt established the Jackson Hole National Monument to protect the land that Rockefeller had purchased but had not been successful in donating to the government. In 1945, the Rockefeller family donated their land to a nonprofit organization they had established, the Jackson Hole Preserve, Inc., to hold those lands until the Park Service had sufficient funds to support them (Huyler 2000). In 1950 Congress finally passed an Act incorporating the Jackson Hole National Monument into Grand Teton National Park.

According to Teton County Land Office records, ownership of Jenny Lake Ranch was Teton transferred from Rockefeller (on behalf of Grand Lodge Company) to Jackson Hole Preserve, Inc. in 1945. At this time the 25 cabins at Jenny Lake

Ranch were in such bad shape that Jack Wentworth, the general manager, recommended closing the ranch down. However, Jackson Hole Preserve, Inc. opted for remodeling and reconstruction of the existing buildings. The existing dining room at the south end of the main lodge was replaced with a larger room and cabins were repaired and outfitted with bathrooms. Four duplex-style cabins were also built at this time (Goodrich et al. 1947). By 1949, Jenny Lake Lodge was once again fully operational and was considered the top concession facility in the Park.

\section{Jenny Lake Lodge}

Interest in dude ranching declined significantly after 1945, as the tastes and demands of recreating Americans changed from "vigorous outdoor activities" to "more sedentary" ways of relaxation (Daugherty 1999). Perhaps indicative of this shifting emphasis on the sightseeing experience over the dude-ranching experience, the Grand Teton Lodge Company renamed the ranch Jenny Lake Lodge in 1951.

During this period plans were developed for a new lodge at Jackson Lake, resulting in diversion of funds and interest from Jenny Lake Lodge. In spite of the improvements undertaken in 1947, the property suffered from inadequate sewage and utility systems and employee housing (male employees slept in tents). When Jackson Lake Lodge opened to much acclaim in 1955, the Park Service suggested closing the operation at Jenny Lake, reasoning that the new lodge combined with a planned cabin facility at Colter Bay would provide sufficient accommodations for Park visitors. However, in 1956, the Secretary of the Interior's National Park Advisory Board met at Jenny Lake Lodge and were so impressed with the property that they recommended that the facility be enlarged instead of being closed (McKinney 1997). This intervention by the national board saved Jenny Lake Lodge from the wrecking ball (Figure 7).

Major renovations began at the end of the 1957 season and coincided with the construction of the outer loop highway leading to Jackson Hole, which considerably improved accessibility by automobile. The Grand Teton Lodge Company hired San Francisco architect Eldridge T. Spencer to design the rehabilitation of the lodge and cabins, and the construction work was carried out by Olson 


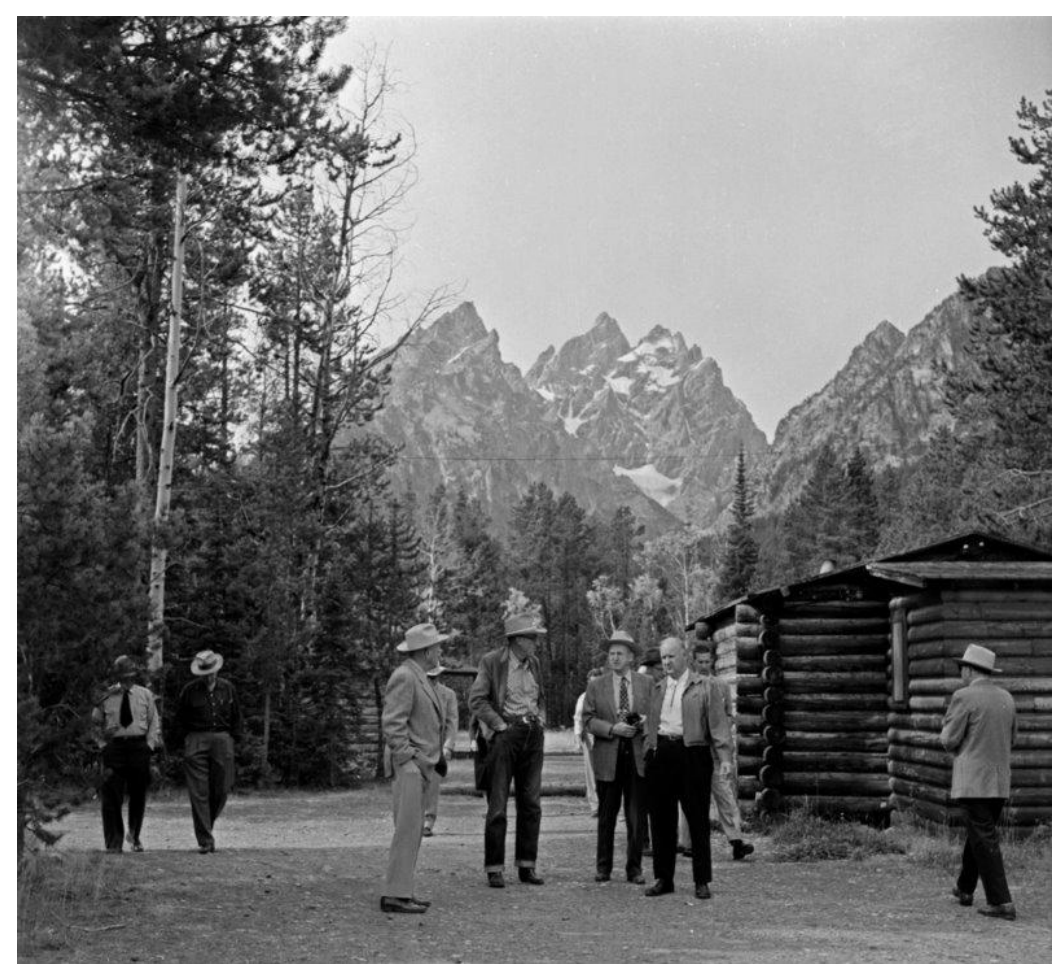

Figure 7. Meeting of the National Park Service Advisory Board, Jenny Lake Lodge, 1956 (Courtesy of Grand Teton Lodge Company)

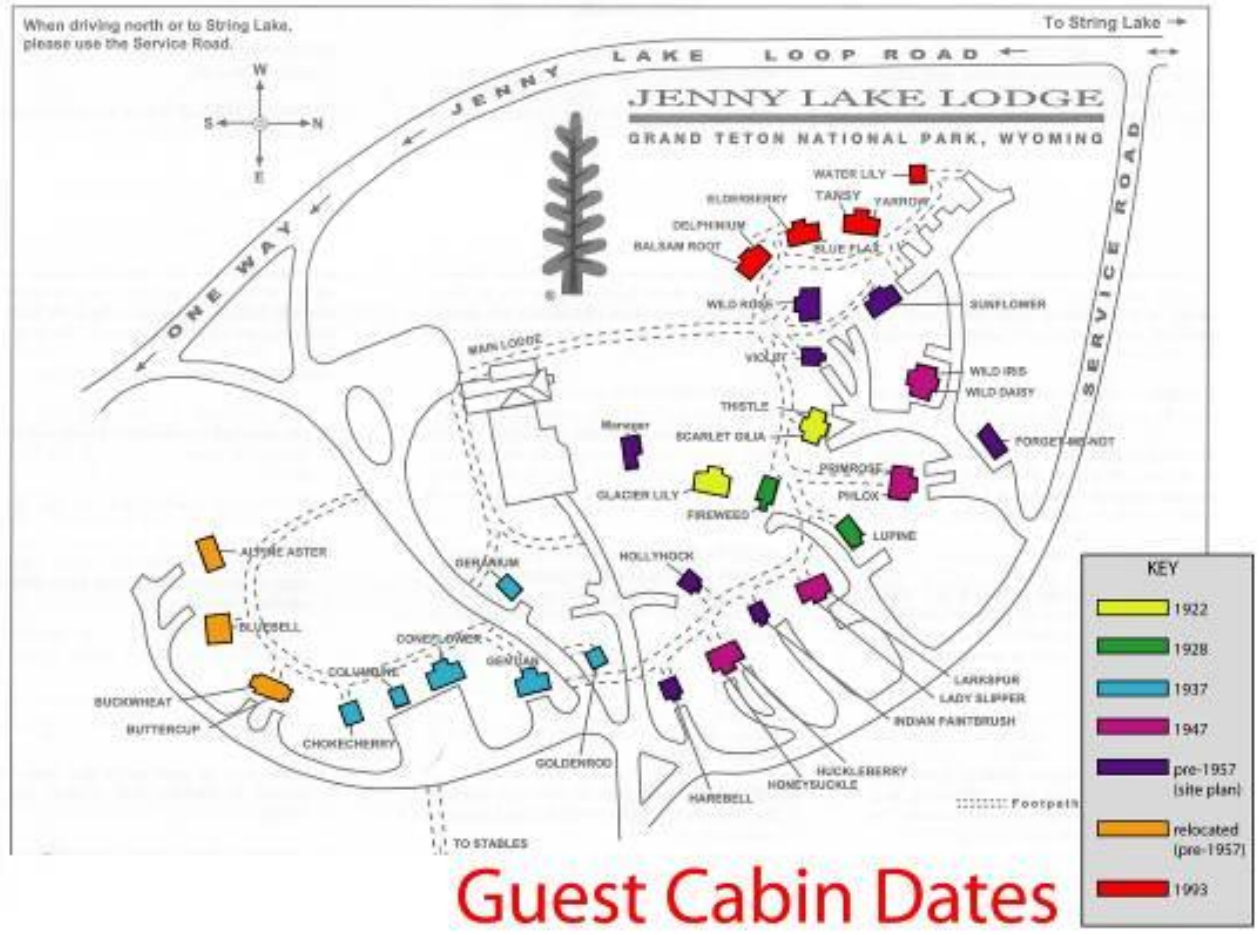

Figure 8. Site plan of Jenny Lake Lodge, showing dates of cabins (Hilery Walker, 2009) 
Construction Company of Salt Lake City. Spencer had collaborated with Gilbert Underwood (architect of Jackson Lake Lodge) on the Ahwahnee Hotel in Yosemite National Park in the 1920s and later worked with Ansel Adams to design the famous nature photographer's home in Big Sur, California in 1961. His wife, Jeanette Dyer Spencer, was interior decorator for the project.

In the 1957 rehabilitation, the massive stone chimney of the main building was extended in height and the front porch floor was replaced with a terrace. A new addition was built off the east elevation that approximately doubled the size of the building. The addition was square in plan and housed the kitchen, offices, employee dining, linen room and other storage spaces.

A 1957 site plan shows all but seven of today's existing guest cabins in their current locations. During the 1957 renovation three cabins were brought in, one from the Blacktail Butte Ranch, one from the Chambers Ranch and one from the Feuz Ranch. Concrete aprons were added to the 35 cottages and electric heaters were installed to replace wood burning stoves. New walkways, roads and parking areas were laid out to better serve the needs of the guests, almost all of whom now arrived by private automobile. Other important improvements in 1957 were new "dormitory-style rooms" for employee housing with washrooms and laundry facilities.

These improvements, coupled with the efforts of a new resort manager, John Love, who was charged with ensuring that "Jenny Lake Lodge reflect the ambiance and the reality of a fine resort for discriminating guests," (McKinney 1997) turned the 1920s dude ranch into an elite escape into the wilderness. A major renovation during the winter of 1986-87 changed the look of the main lodge considerably. Tony Grace's original 30 ' by 30 ' hiproofed $\log$ structure still forms the nucleus of the reconstructed lodge, comprising most of the dining room; however, the original sapling ceiling was removed at this time. The kitchen was extended to the south, and a new stone chimney was constructed on the south end. In 1993 four new log cabins were added to the guest area.

At present, Jenny Lake Lodge has 29 cabins able to accommodate up to 114 visitors per night from early June to early October; the average occupancy rate during the summer months is $90 \%-$ 95\%. The lodge has entertained such prominent visitors such as Monaco's Princess Grace and her family, as well as Walt Disney, Angie Dickinson, Norman Rockwell and Burt Bacharach. But what is particularly noteworthy is the intense loyalty of the lodge's regular guests. According to Jenny Lake Lodge General Manager Scott Greene, $75 \%$ of the guests are return visitors and $50 \%$ of guests return annually. Informal interviews conducted in the course of documentation revealed many guests who return year after year, to enjoy the ambience of the lodge, the beauty of the Tetons and the special friends they have made while staying at Jenny Lake. The lodge encourages this tradition by guaranteeing that guests can book their cabins for the same days the following year, if they make their reservations before they depart.

\section{Architecture and Landscape}

Jenny Lake Lodge exhibits the "Dude Ranch Architecture" common to early $20^{\text {th }}$ century dude and guest ranches throughout the West. Although built long past the pioneer period, the lodge and cabins mimic pioneer architecture in their peeled log construction, saddle notching, purlin roofs and porches. This architecture reflects "the deliberate attempt (culturally rather than environmentally imposed) to create a 'western style' attractive to eastern guests" (Caywood and Hubber 1997).

From Tony Grace's original lodge and cabins built in 1922 to the latest additions in 1993, this architectural tradition has been maintained. By the 1950s, the cabins had all been improved with generous porches that extend significantly over the entrances and are supported by vertical log posts at the ends (see Figure 6). This building type, dubbed the "Rocky Mountain Cabin," is described as follows:

The "Rocky Mountain Cabin" extended the gable end over the door to an average of 50 percent beyond the front of the cabin. The length of the extension often required vertical post supports at the roof end. For all practical purposes, this roof functioned both as a porch and as an additional living area used in the warmer months for sleeping, cooking and other activities (Caywood and Hubber 1997).

In 1957, San Francisco architect Eldridge Spencer was hired to design a major rehabilitation of Jenny Lake Lodge, that included renovation of and additions to the lodge; cabin renovations; moving in three cabins from other ranches; and landscaping including pathways and driveways. 
In his design Spencer did not stray far from the "Dude Ranch Rustic" architectural tradition (Figure 9). The 1950s were a time when Rocky Mountain Rustic Architecture was embraced as a viable style in which trained architects designed: "formal Rustic architecture represented the deliberate attempt -usually an architect's deliberate attempt -- to convey historical images and to meld man-made resources with their wilderness environment" (Caywood and Hubber 1997). Aside from the kitchen addition, the only concessions to modern architecture were the asymmetrically angled concrete aprons outside the cabins, most of which were squared off in later renovations.

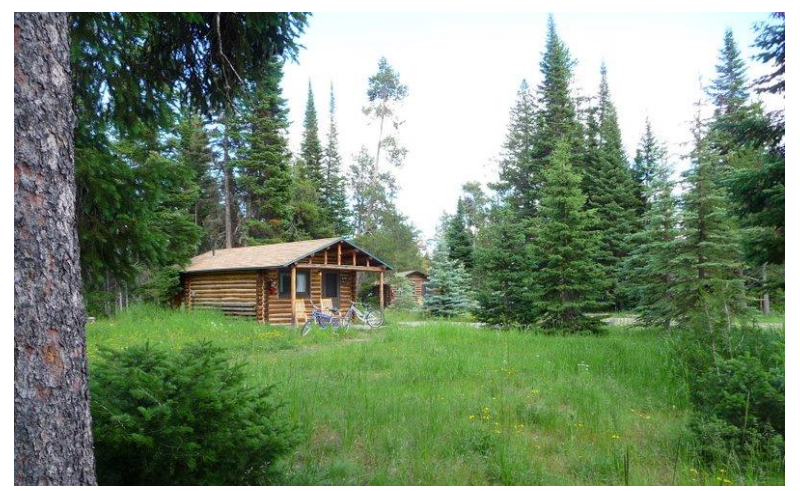

Figure 9. Single cabin exhibiting the "Dude Ranch Rustic" style, set in a natural landscape (Mary Humstone, 2009)

The layout and landscaping of the Jenny Lake Lodge property are also in keeping with the local dude ranching tradition, in which cabins were arranged informally around a central lodge, with the corral and stable house isolated downwind from the guest compound, mostly natural landscaping with large trees and native shrubs, grasses and wildflowers is representative of the natural environment preferred for dude ranches. Although Jenny Lake Lodge incorporated the private automobile with individual parking spaces, this was done through driveways hidden behind the cabins and thus the lodge never took on the appearance of an auto court, with clustered cabins around a central drive (Figure 8). The cabins are arranged in a seemingly random pattern, and this combined with the forested nature of the site makes it difficult to ascertain exactly how large the property is, and how many cabins there are.

The property also includes an employee area, an essential but often overlooked element of the dude or guest ranch. The employee area contains cabins that are similar but not identical to those of the guest area, as well as communal facilities such as a bathhouse, recreation center, exercise court, horseshoe pit, and fire pit (Figure 10). The employee buildings range in size from singles to triplexes and dormitories, and like the guest buildings they are log buildings, most with purlin roofs. More so than the guest area, the employee area represents the common Western tradition of moving buildings from other properties. This practice was especially common during the Snake River Land Company's period of ownership (1927 to 1950), since the land-acquisition company often dismantled the homesteads, ranches and tourist facilities it purchased. The employee area lacks the trees and other natural vegetation found in the guest area, and cabins appear to be arranged in a random pattern.

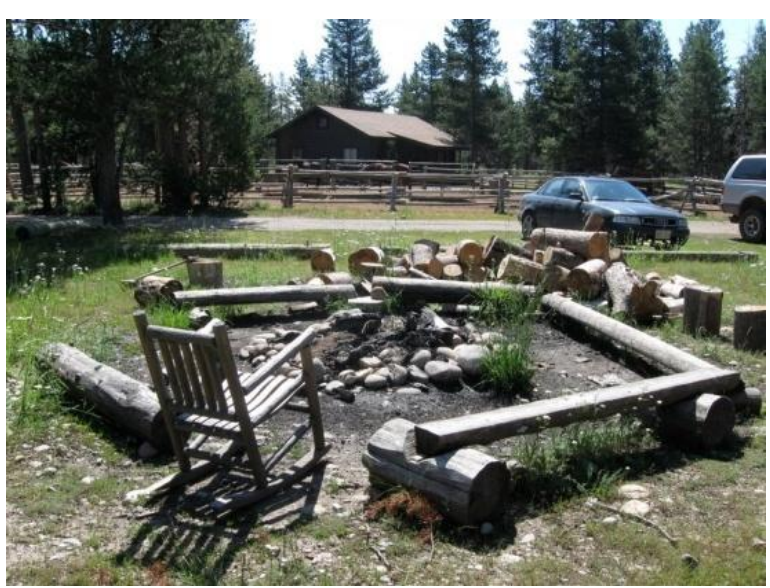

Figure 10. Fire pit in the "Employee Area," with corrals and stable house in the background (Hilery Walker, 2009)

\section{$\uparrow$ CONCLUSION}

In order to qualify for listing on the National Register of Historic Places, properties must meet at least one of four criteria for significance in American history and culture, and must retain enough physical integrity to demonstrate their significance. The researchers determined that the Jenny Lake Lodge is eligible for the National Register of Historic Places within the context of "Dude Ranching and Tourism" as defined in a previous research report, the Grand Teton National Park Multiple Property Submission. The property retains integrity of location, design, setting, materials, workmanship, feeling, and association, and meets two National Register criteria: Criterion A, "associated with events that have made a significant contribution to the broad patterns of our history," and Criterion C, "embodying the distinctive characteristics of a type, period, or method of construction."

Jenny Lake Lodge is significant as one of the longest operating tourist establishments in Grand 
Teton National Park, reflecting the changes in the tourism industry over the course of the $20^{\text {th }}$ century. The property has provided Park visitors with lodging, food and outdoor activities almost continuously for 87 years. In both its physical layout and its social history, Jenny Lake Lodge combines attributes of both a dude ranch and a guest lodge or hotel. Although the property has never given guests an opportunity to participate in the daily chores of cattle ranching, guests regularly participate in other traditional dude ranch activities such as fishing, hiking, and recreational horseback rides. Jenny Lake Lodge also represents the history of Grand Teton National Park, since it was one of the properties purchased by J.D. Rockefeller's Snake River Land Company for inclusion in the Park, and has been at the center of many debates over what visitor amenities the Park should offer.

Jenny Lake Lodge is also significant under Criterion $\mathrm{C}$ as a cultural landscape embodying concepts of Western-style hospitality, including rustic cabins and a comfortable lodge and dining room, set in a natural landscape with a magnificent view. Most of the 47 buildings on the property are 50 years old or more, and all represent the architectural tradition known as "Dude Ranch Rustic," with $\log$ construction, rectangular floor plans, low- to medium-pitched purlin roofs, open porches and simple interiors with exposed log walls.

The predominately natural landscaping featuring large trees and native shrubs, grasses and wildflowers is typical of the valley's dude ranches, and the more "civilized" features such as driveways, individual parking areas, pathways and croquet lawn represent the guest ranch tradition. The employee area represents the behind-the-scenes people and activities that create the vacation experience. Overall, the site retains the feeling and association of an early $20^{\text {th }}$ century guest ranch. Although individual buildings on the property have undergone renovation, their location and design continue to represent the property's long tradition of Westernthemed recreation.

\section{$\uparrow$ Literature Cited}

Daugherty J. 1999 A Place Called Jackson Hole: A Historic Resource Study of Grand Teton National Park. Moose (WY): Grand Teton Natural History Association.
Caywood J, Hubber A. 1997. Grand Teton National Park Multiple Property Submission. National Park Service, Grand Teton National Park.

Goodrich, Laviolette and Wilkins. architects. 1947. Jenny Lake Ranch Deluxe Cabins.

Greene S. (2009, July 14). (Manager, Jenny Lake Lodge). Personal interview.

Huyler, J. 2000. And That's the Way it Was in Jackson Hole. Jackson (WY): Jackson Hole Historical Society.

McKinney M. 1997. The Danny Ranch, Jenny Lake Ranch, and Jenny Lake Lodge. Augusta, Georgia: Mary McKinney.

Righter R. 1982. Crucible for Conservation: The Creation of Grand Teton National Park. Boulder (CO): Colorado Associated University Press.

Toogood AC. 1974. "Brief History of Jenny Lake Area." Denver (CO): National Park Service Denver Service Center.

\section{$\uparrow \quad$ RESEARCH SOURCES}

Grand Teton Lodge Company files, Jackson Lake Lodge, Moran, Wyoming.

Grand Teton National Park Historian's Office (Grand Teton Lodge Company files), Moose, Wyoming.

Jackson Hole Historical Society ("Danny Ranch \& Jenny Lake" vertical files), Jackson, Wyoming.

Teton County Assessor's Office records, Jackson, Wyoming.

Teton County Land Office records, Jackson, Wyoming. 